\title{
Travel and Leisure Activities, Motivation and Behavior of Young Bangladeshi Tourists
}

\author{
Shohel Md. Nafi, MBA \\ Lecturer, Department of Tourism and Hospitality Management, \\ Daffodil Institute of IT, Bangladesh \\ Tanvir Ahmed, MBA \\ Department of Tourism and Hospitality Management, \\ University of Dhaka, Bangladesh
}

Doi: 10.19044/esj.2018.v14n5p341 URL:http://dx.doi.org/10.19044/esj.2018.v14n5p341

\begin{abstract}
The purpose of this study is to find the motivational factors and travelling patterns of young tourists at home and abroad. Leisure activity and vacations aren't considered as luxury anymore. In their busy life Vacation is one of the core elements of mental support system. Despite an increasing interest in the market size of young travelers, economic potential and their desire to travel, relatively little is known about their travel motivation, expectation and intention. Therefore, this study aims to provide insights of young Bangladeshi travelers' lifestyles and travel intentions. This study mainly focuses on the behavioral and motivational aspects of the tourists when they choose a vacation and in a vacation. The survey questionnaire is divided into three sectors; first part focuses on the demographic characteristics of the respondents, second part focuses on the motivational and behavioral aspects of young tourists; third part describes the travel motivation and behavior of outbound tourists. The sample of 200 young tourists has been selected based on Simple Random Sampling method to collect data. The survey data are being analyzed in a descriptive manner. SPSS 20.0 software has been used to analyze the primary data. This study used frequency analysis, table and chart to analysis data. The study suggests that the way of leisure spending have been altering over the period of time. The vibrant young travelers of Bangladesh are bringing their constructive influence in this business for the last decade with their ever changing test and demand being constantly updated with worldwide trend.
\end{abstract}

Keywords: Leisure Behavior, Motivation, Tourism, Young Tourist 


\section{Introduction}

The process to accurately forecast recent travel behavior pattern and to identify travel motivational factors can play a vital role determining the policy making process, destination management and tourism product development. In order to predict travel behavior it is essential to identify distinctive traits of a person that influences visitors decision making process, which will ultimately lead to the understanding of the positive and negative motivational drivers influencing destination preferences of the tourists (March \& Woodside, 2005; Laws, 1995; Holloway, 2004). Therefore with the understanding of tourist behavior and sufficient information, strategies can be developed and implemented to increase the demand for tourism related products (March \& Woodside, 2005; Papatheodorou, 2006)

Tourism literature has reported that people's perception of travelling lies in the results of travelling attitudes, perceived awareness, understanding and information about tourism based resources and images of destinations. In the early 80's, several 'leisure researchers' first began to research 'tourism topics' from a social psychological perspective (Iso-Ahola, 1989), although the common linkages between these two arena were commonly acknowledged. Moreover, current definition of leisure included both being undertaken in people's free time, being regarded as pleasurable, intrinsically motivating and a rewarding experience that has formed the basis of the subjective definition of leisure (Neulinger, 1974).

On a trip travelers usually participate in unusual activities. Leontido (1994) and Carr (2002) found that tourists often act in a more unconventional and less reserved way in contrast to their regular behavior during leisure time at home. That's the reason social psychological theories are now being applied to study of leisure by several modern leisure researchers, mostly focusing on the deeper stimulation, mind-set and feelings of people's leisure behavior. In other words, to measure the diversity, rate of recurrence and value of the 'experience' has more significant value now then previously perceived.

Traditionally young tourists were dependent on the decisions of other key persons of their family. But, in recent years this particular market segment is becoming more independent, technologically advanced and drawn to novelty of the tourism product. This dramatic demographic shift in the last decade has totally changed the usual perception of the policy makers. Specially, the young market has been showing both the aspiration and capability to acquire a wide variety of tourism products and also has a tendency to take longer vacations which ultimately guarantees more scope for business opportunities (Ian \& Musa, 2008; Richards \& Wilson, 2003).

As an emerging economy of south Asia, Bangladeshi youths are also evolving. Leisure activity and vacations aren't luxury anymore. In their busy life vacations are one of the core elements of mental support system. The 
market has a clear understanding of this segments potentiality, that's why they focused on young traveler's potential desire to travel, to turn into actual demand for tourism product and services. All these ultimately lead commercial businesses to constantly bringing innovative, thrilling and pioneering development in leisure experience products. Ultimately creating more flexible and affordable vacation options with additional leisure activities tailored only for this specific lucrative market.

But unfortunately, though the market size of young travelers is increasing and significant economic potentiality has been showing many positive signs. But relatively very little is known about their travel motivation, expectation and intention. Therefore, this study aims to provide insights of young Bangladeshis travel lifestyles and travel intentions by focusing on their travel behavior and motivation.

\section{Literature Review}

In this study, young travelers are defined as young Bangladeshi travelers aged between 18 and 34 years old. At the age of 18, a person is considered or perceived as an adult in Bangladesh and allowed to travel with minimal supervision. First of all, it is important to clarify the term 'youth'. Recently UNWTO has declared the age of youth to between 18 to 34 years (Prayag et al., 2013; UNWTO, 2012) which is used in this study as age bracket of the youth. Previous academicians also referred this age bracket to represent youth (Holmes et al., 2013; Prayag et al., 2013). However, there is no universally agreed definition of youth travelers in terms of age (Chen et al., 2013). Moreover, the importance and impact of young travelers have recently been esteemed by the policy makers in all over the world that helps to the policy development regarding youth travel.

The majority of previous researches on young travelers mainly focus on the backpackers (Ian \& Musa, 2008; Murphy \& Pearce, 1995) and students (Chadee \& Cutler, 1996; Kim \& Jogaratnam, 2002; Reisinger \& Mavondo, 2004; Sung \& Hsu, 1996). Generally local community and business benefited more from the adventurous young travelers (d'Anjou, 2004). But the current research has been focused on the leisure activities and vacation motivation of young tourists.

Leisure activities are closely related to the way of life of the people. Several researchers have already identified the concept of leisure. Szántó (1967) defined leisure time as "a time frame and part of non-work frame, which is left off for activities that is economic, social, physiological constraint-based activities". So, leisure time can be denoted as all the activities in which people take part voluntarily in their free time outside their usual residence. Generally people involved in various types of leisure activities like 
sports, shopping, visiting tourist place in home and abroad, have fun or relax, visiting friends and relatives, excursions etc.

Normally vacation travel is an experience and essentially an intangible product (Ahmed et al., 1998). The production and consumption of vacation travel is take place at a same time. For that reason traveler or consumer directly involved in the product creation process that influence on their experience. In recent time, vacation travel has become more popular to the youth as a result of increased leisure time, technological processes and income which have freed the movements of money and people (Yau \& Chan, 1990).

Traveler's decision about destination selection is a complex procedure relating with individual's perception, motivation, previous experience, attitude, information search and intention (Shih, 1986). Travel destination includes both natural and manmade places where individuals spend their free time. They include national parks, amusement parks, shopping facilities, historical sites, cultural resources, natural scenery, lodging facilities, food and beverages establishments, entertainment facilities, recreational facilities, and the people and culture of different travel destinations.

Motivation is one of the primary reasons for individuals' travelling behavior and motivation is also important to understand the tourists decision making process, in addition to evaluate the successive fulfillment of tourist's expectations (Wall and Mathieson, 2006). Consequently, motivational factors are importance to understand the destination choice decision of the young tourists and to design marketing program for them. Crompton and McKay (1997) illustrate that, this kind of importance lies in three reasons: i) understanding tourist motivations would pave the way for creating better products and services; ii) motives must be identified and prioritized first before a destination marketer can understand tourist decision-making processes; and iii) satisfaction with tourism experiences is intrinsically related to initial motives of tourists.

The success of a travel destination depends on the three basic factors; attractions; amenities or facilities and its accessibility (Holloway, 1986). These factors are interrelated with each other and collectively create the satisfaction. Moreover, Goodrich (1978) found that while traveling tourists had considered four important factors in their travel planning: entertainment, opportunity of purchase, comfortable climate and price of the product. On the other hand, young travelers exhibit one of the four different types of travel motives: experience seeking, relaxation seeking, sociability and contributing to the destination (Richards \& Wilson, 2003).

\section{Methodology}

In this study descriptive statistics is used for data analysis. A structured questionnaire is used to collect primary data from the respondents. The 
questionnaire is divided into three parts; socio-demographic characteristics of the respondents is given in part one, part two consists of questions on young tourists motivation and travel behavior in domestic travel choice and young tourists motivation and behavior in international travel choice is shown in part three. A total of 200 individual tourists have been surveyed through a questionnaire. The sample of 200 young tourists has been selected based on Simple Random Sampling method to collect data. The survey data are being analyzed in a descriptive manner. SPSS 20.0 software has been used to analyze the primary data. This study used frequency analysis, table and chart to analysis data.

\begin{tabular}{|c|c|c|}
\hline & Target Population & Young Tourists (Age range: 18 to 34 ) \\
\hline & Sampling Technique & Simple Random sampling \\
\hline & Sample Size & 200 \\
\hline & Data Used & Primary and secondary \\
\hline & Data Analysis & SPSS 20.0 \\
\hline
\end{tabular}

\section{Snapshot of Research Design}

\section{Data Analysis and Findings}

This chapter has been divided into three parts. In the first part, socioDemographic characteristics of the respondents have been discussed. In the second part, travel behavior and motivations of young tourists has been elucidated. And finally, attitude towards travel behavior and motivations of respondents about international travel has been discovered.

\section{- Part -1 Socio-Demographic Characteristics}

In this section, the background information of the respondents of the survey is presented. Particularly, it provides the socio-demographic information about respondents' gender, age and education level. It also provides information about the respondents' travel pattern like the frequency of the visit, length of stay and daily expenditure during the stay.

Table 1: Demographic Profile of Respondents

\begin{tabular}{|c|c|c|c|}
\hline Variables & Categories & No. of Respondents & Percentage \\
\hline \multirow{3}{*}{ Gender } & Male & 137 & 68.5 \\
\cline { 2 - 4 } & Female & 63 & 31.5 \\
\hline \multirow{3}{*}{ Age } & $20-25$ & 172 & 86.0 \\
\cline { 2 - 4 } & $26-30$ & 6 & 3.0 \\
\cline { 2 - 4 } & $31-35$ & 22 & 11.0 \\
\hline \multirow{3}{*}{ Education level } & H.S.C & 35 & 17.5 \\
\cline { 2 - 4 } & Undergraduate & 142 & 71.0 \\
\cline { 2 - 4 } & Graduate & 23 & 11.5 \\
\hline \multirow{3}{*}{$\begin{array}{c}\text { Monthly Family } \\
\text { Incomes }\end{array}$} & below 20,000 & 28 & 14.0 \\
\cline { 2 - 4 } & $21,000-30,000$ & 27 & 13.5 \\
\cline { 2 - 4 } & $31,000-40,000$ & 75 & 37.5 \\
\cline { 2 - 4 } & $41,000-50,000$ & 43 & 21.5 \\
\cline { 2 - 4 } & over 50,000 & 27 & 13.5 \\
\hline
\end{tabular}


Table 1 shows that among 200 respondents of this study, 137 are male that is 68.5 percent of total respondents and 63 are female that is accounting for 31.5 percent. To conduct study focused on young tourists, the survey was conducted by keeping in mind about the targeted age limit. Among the participants of this study 86 percent of them are from the age range of 20-25 years, 11 percent are from 31-35 years and only 3 percent are from 26-30 years age range. On the other hand, this study targeted to find the activities, motivations and behaviors of the young tourists, the participants should have a strong educational background to have a developed sense about their actions and choices. For that reason, the table shows that 71 percent of the respondents have studied undergraduate level while 17 percent have completed higher secondary followed by 11 percent graduate participants. This study found that 37 percent of the participants' comes from the families that have a family income in between taka 31,000-40,000 and 21 percent came from the income range of taka 41000-50,000.

Part 2: Leisure Pattern and Preference of Domestic Tourists:

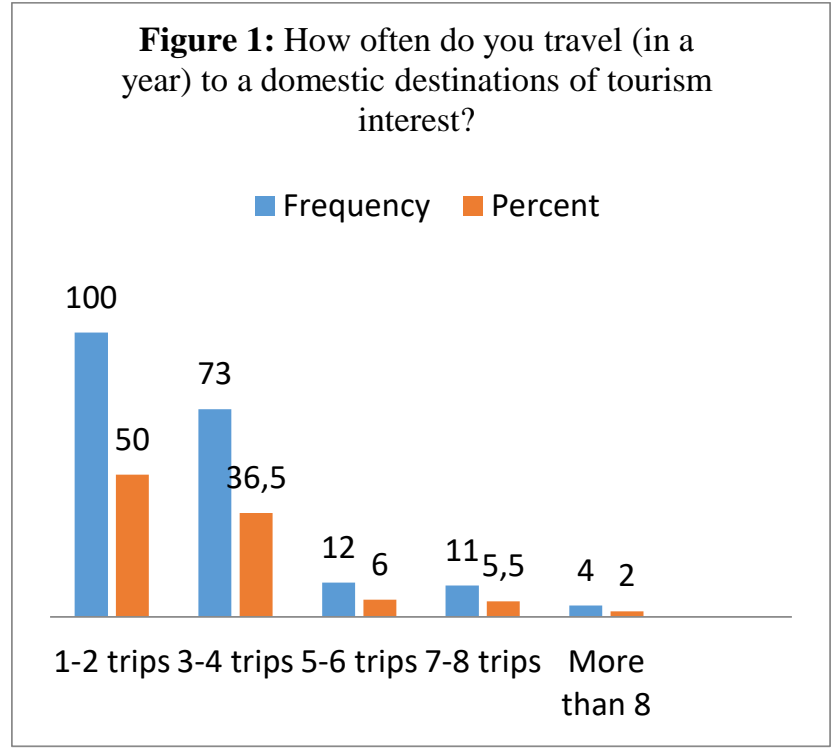

Many Bangladeshi travelers usually make a trip to their native village once a year during two religious 'Eid festivals'. However, there are various recreational tours with family, colleagues and classmates. From the figure 1 , it is identifiable that $50 \%$ of the participants make a domestic tour, once or twice a year which makes the most preferred option for this question. $36 \%$ participants expressed that they make 3-4 trips a year. Moreover, this study also found some enthusiastic tourists who usually travel 7-8 trips or more than 8 trips in a year. 
Figure 2: How do you organize your holiday?

$$
\text { Frequency Percent }
$$

\section{2}

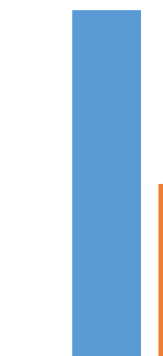

71

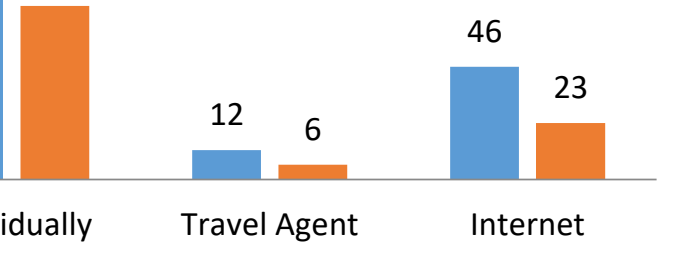

Figure 3: With whom do you travel or you prefer to travel?

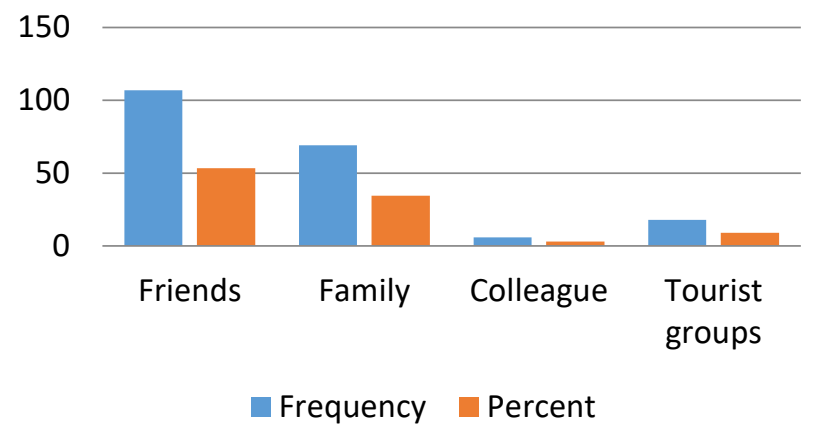

Figure 4: In which season do you like to travel in Bangladesh?
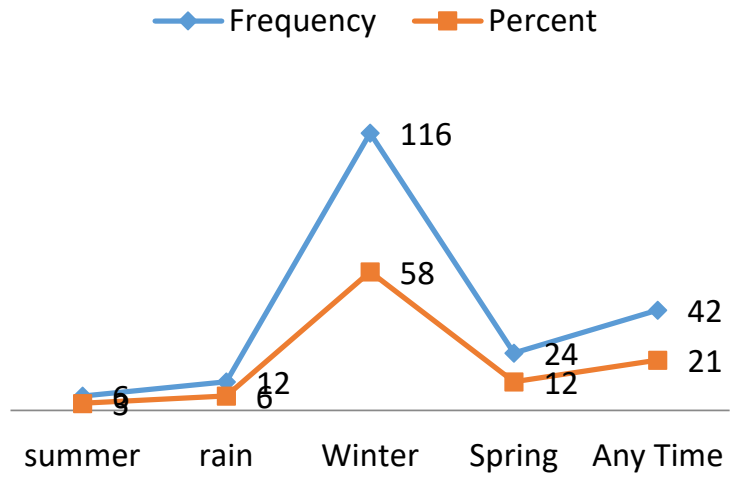


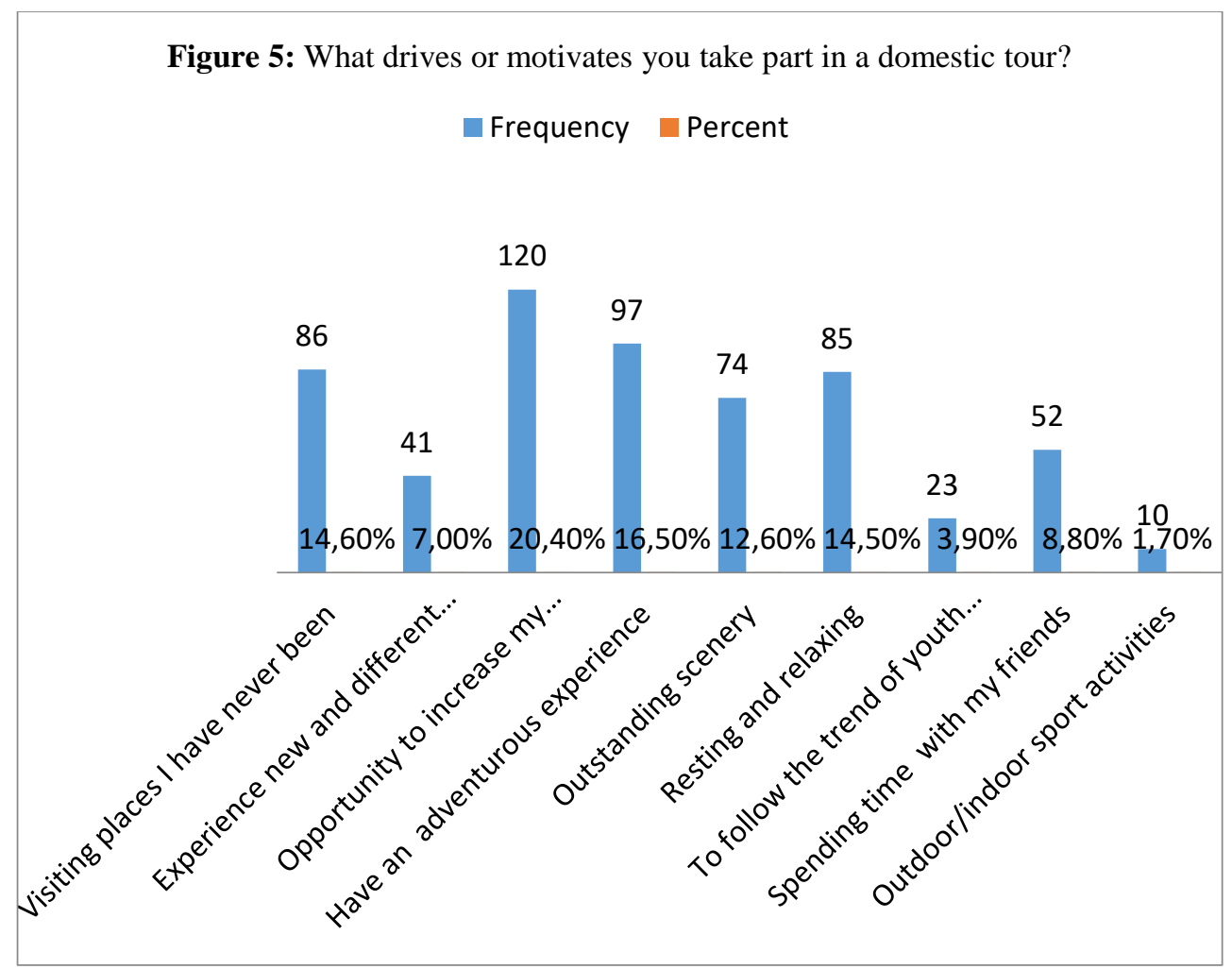

To find out the most imperative motives to go for a domestic travel, participants are asked to mark their top three top motives out of several options. From the figure 5 we can identify that, opportunity to increase knowledge is the most vital motivator with $20.40 \%$ preference, possibility for having an adventure has secured the second position with $16.50 \%$ preference and the experience to be in a new place is in third position with $14.60 \%$ preference.

Figure 6: What type of Tourism destination attracts you most?

\section{Frequency $\quad$ Percent}

80

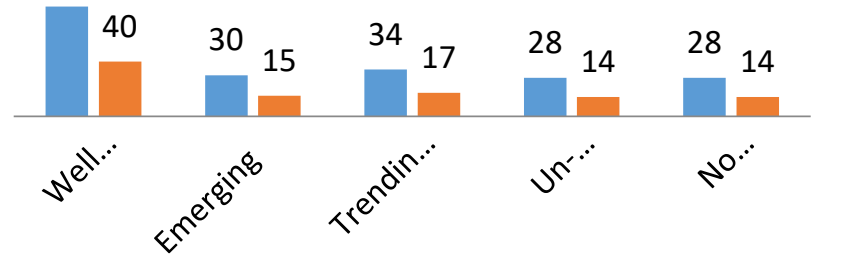

This question was asked to find out reasoning behind a travelers decision to choose a destination over others. And this study has found that well known destinations are far more preferred (40\%) than any other options available for the travelers. 
Figure 7: Please state your preferred mode of domestic transportation?

$$
\text { Frequency } \square \text { Percent }
$$

\section{6}

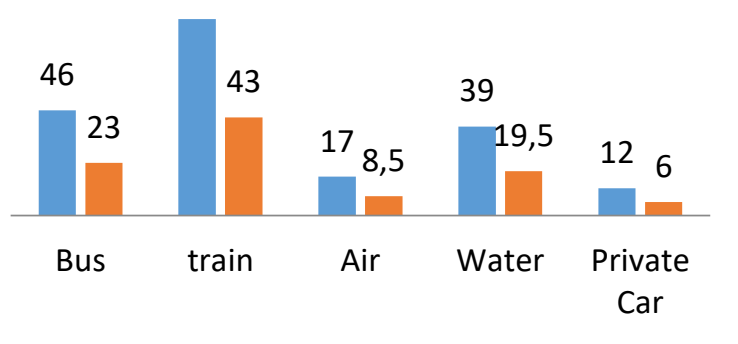

Though the common perception is that, Bus is the most preferred mode of transportation in Bangladesh because of its flexible schedule and accessibility. But this study found train outnumbered the popularity of bus in the time of travelling for vacation. Train is leading the leader board with $43 \%$ preference followed by $23 \%$ preference of Bus and 19.5\% preference of water vassals.
Figure 8: How much do you typically spend per day on a typical domestic tour?
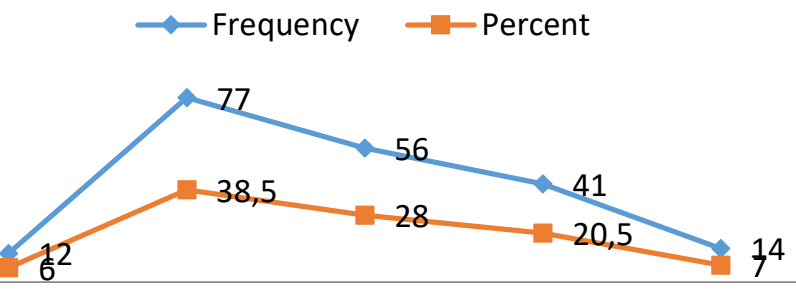

Less than $1100-3000 \quad 3100-5000 \quad 5100-7000$ more than 1000

7000
Bangladeshi youth tends to spend mildly on trips. Because of them are students. According to this study $38.5 \%$ of the respondents spend 1100-3000 per day while $28 \%$ of them spend 3100-5000 per day.

Figure 9: From where do you get most information?

$$
\text { Frequency } \quad \text { Percent }
$$

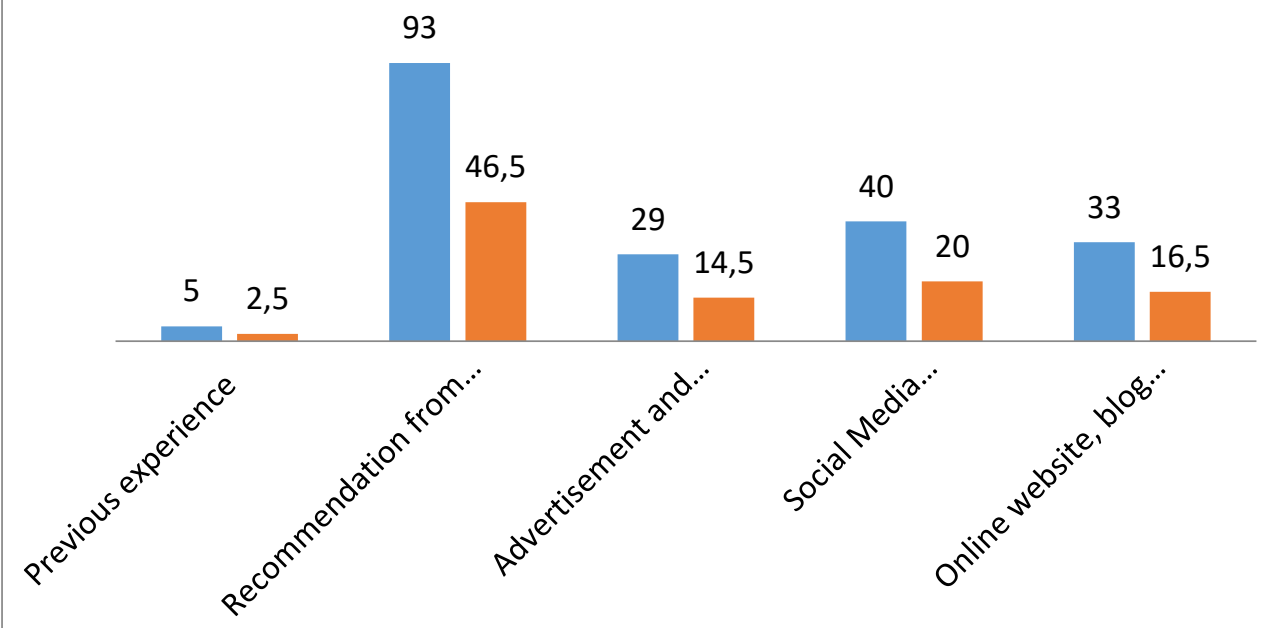


From the collected data set for this study, it can be found that Most of the Young Bangladeshi Tourists prioritize their decisions of choosing a destination of their acquired information. And this study shows they mostly collect it from Friends and Family (46.5\%) as their trusted source. Though, Social media is relatively a new concept, but relatively it is imposing a great influence over the travelers' information gathering process.

Figure 10: What is your preferred length of stay at a domestic destination?

Frequency Percent

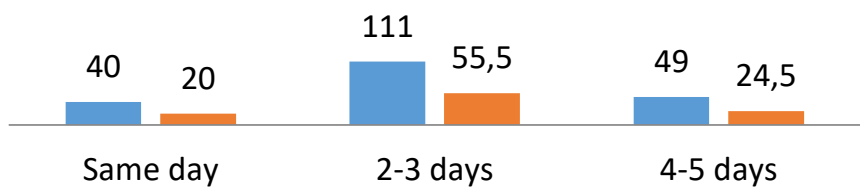

Figure 11: Please choose your top three preferred leisure activities while travelling in Bangladesh

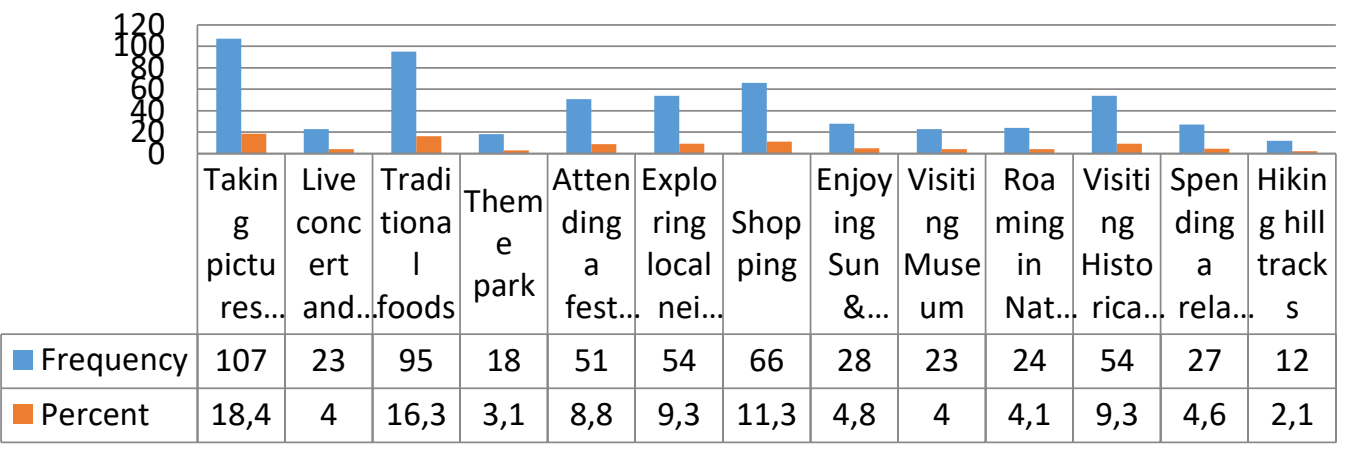

Respondents are asked to choose their most preferred leisure activities in Bangladesh while they take a vacation. For that reason, they had several options including an open ended one. From the table we can understand that 'Taking pictures to preserve memory' is leading the preference table with $18.4 \%$ preference. This is understandable as traditionally, most of respondents' considers leisure activity as enjoyable moments and capturing these moments enables them to relive those moments. Surprisingly foods has secured second position in the chart while this country has always considered consuming food as necessary items not a mean of experiencing luxury . 
Figure 12: When do you participate in tourism and leisure activities?

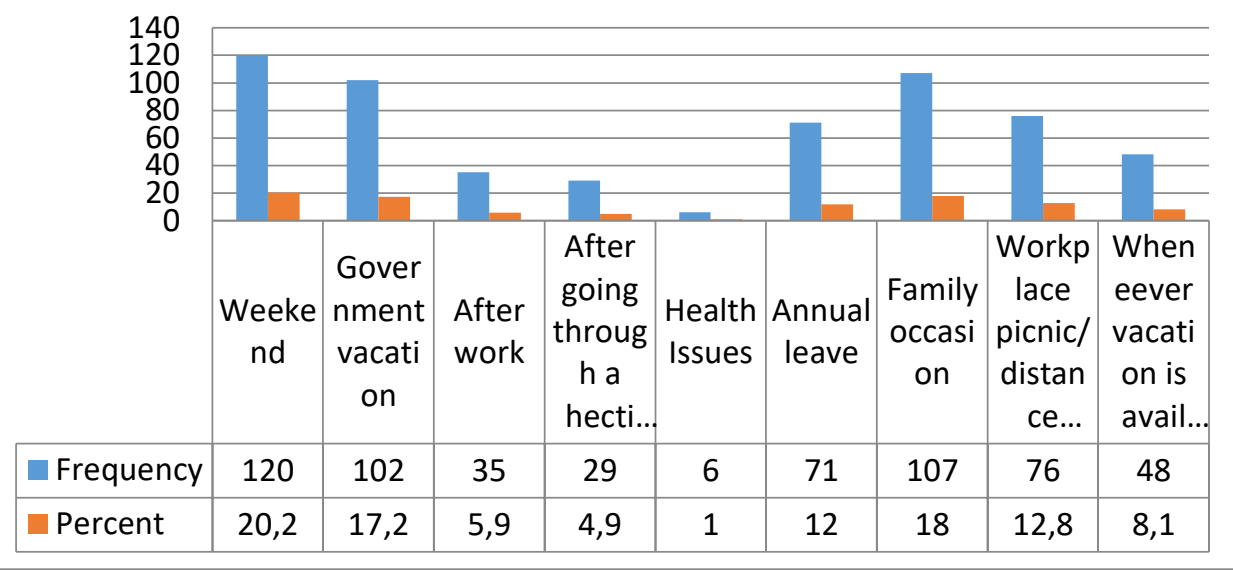

Figure 12 intended to find link between the travelling time and the type of travel. Here, 'Weekend' is leading the table with $20 \%$ preference. But, Family occasion (18\%) and "Govt. Vacation" (17.2\%) is very close competitor.

Figure 13: In case of choosing an activity while traveling in BD what factor mostly influences you?

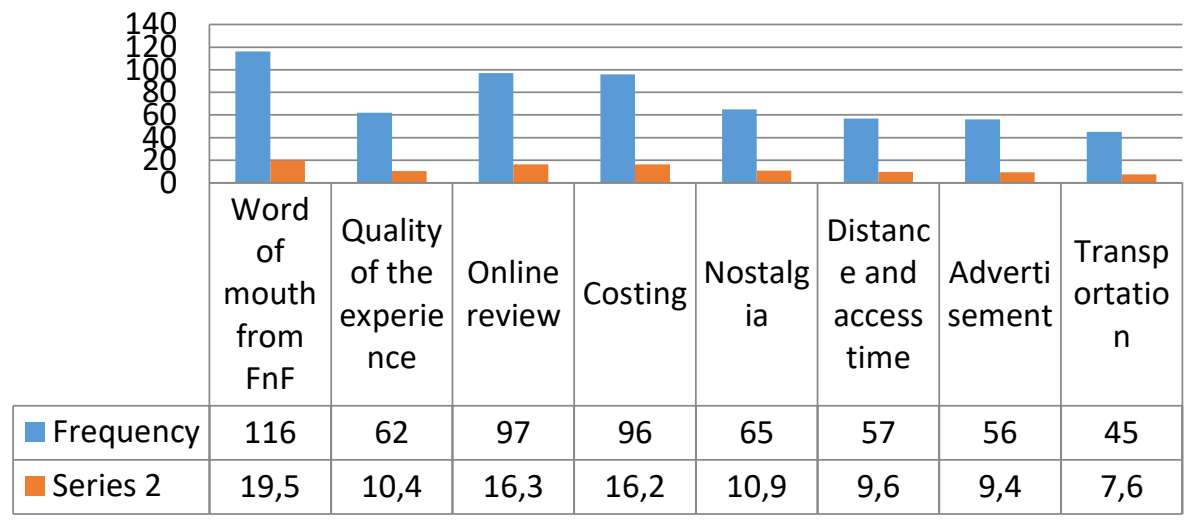

From the data of this study we can assume that Young Bangladeshi tourists tend to be highly influenced by the assessment of Friends and Family. The next two preferred influencers are, online review and costing. 


\section{Part 3: Leisure Pattern and Preference of International Tourists}

Figure 14: Have you ever been to abroad?

Frequency Percent

\section{6}

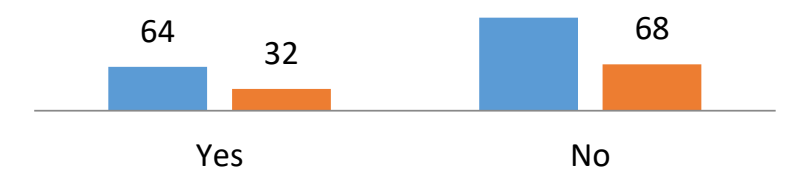

In the last part of this study focused on the leisure pattern and preference of young tourists when they travel abroad. This study revealed that only 32 percent respondents have ever visited abroad.

Figure 15: What drives or motivates you take part in an international tour?

\begin{tabular}{|c|c|c|c|c|c|c|c|c|c|}
\hline & $\begin{array}{c}\text { Visitin } \\
\text { g } \\
\text { places } \\
\text { I have } \\
\text { never } \\
\text { been }\end{array}$ & $\begin{array}{c}\text { Experi } \\
\text { ence } \\
\text { new } \\
\text { and } \\
\text { differe } \\
\text { nt... }\end{array}$ & $\begin{array}{c}\text { Oppor } \\
\text { tunity } \\
\text { to } \\
\text { increa } \\
\text { se my } \\
\text { kno... }\end{array}$ & $\begin{array}{c}\text { Have } \\
\text { an } \\
\text { adven } \\
\text { turous } \\
\text { experi } \\
\text { ence }\end{array}$ & $\begin{array}{c}\text { Outsta } \\
\text { nding } \\
\text { scener } \\
y\end{array}$ & $\begin{array}{c}\text { Restin } \\
\text { g and } \\
\text { relaxin } \\
\mathrm{g}\end{array}$ & $\begin{array}{l}\text { To } \\
\text { maint } \\
\text { ain } \\
\text { social } \\
\text { status }\end{array}$ & $\begin{array}{c}\text { Outdo } \\
\text { or/ind } \\
\text { oor } \\
\text { sport } \\
\text { activiti } \\
\text { es }\end{array}$ & others \\
\hline$\leadsto$ Frequency & 33 & 4 & 25 & 15 & 33 & 12 & 11 & 15 & 6 \\
\hline- -Percent & 21,4 & 2,6 & 16,2 & 9,7 & 21,4 & 7,8 & 7,1 & 9,7 & 3,9 \\
\hline
\end{tabular}

As a developing country not most of the people are affluent enough to travel internationally but in recent years due to economic development and Governments initiatives to reduce Visa related obstacles we have seen a significant change in the mindset of the Bangladeshi travelers. International tour is mostly trending among youngsters of Bangladesh. This study wanted to investigate about the motivators for international travel. With $21.4 \%$ both 'Opportunity to Visit new place' and 'outstanding scenery' has secured the position of most preferred motivator. With $16.2 \%$ preference Opportunity to increase my knowledge e is in second position. Lastly, opportunity to have an adventure and to enjoy Outdoor/indoor sport activities has jointly secured the third position as motivator for international travel. 
Figure 16: How do you organize your holiday?
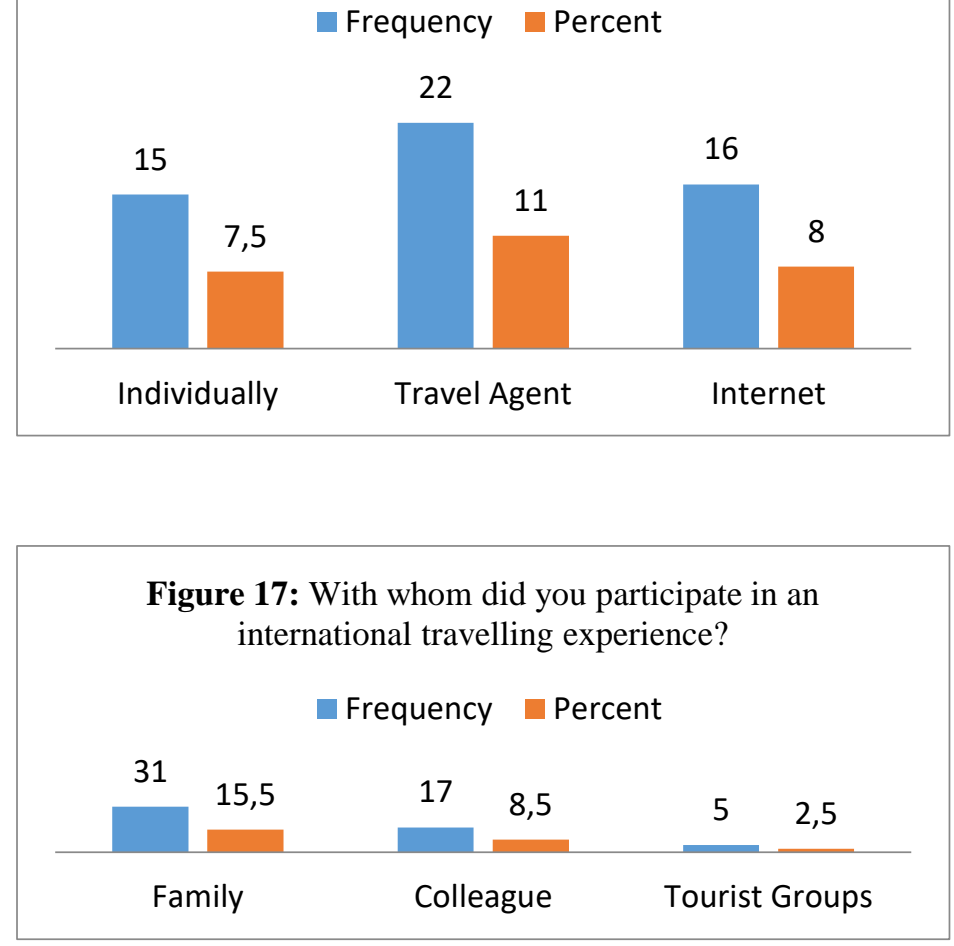

This Figure shows that about 11 percent respondents preferred travel agent when they taken an international tour and 8 percent arranged their vacation on internet and about 7.5 percent preferred individual arrangement.

\section{5} percent respondents preferred to travel with their family when they travel abroad, 8.5 percent preferred to travel with their colleagues and 2.5 percent with the tourist groups.

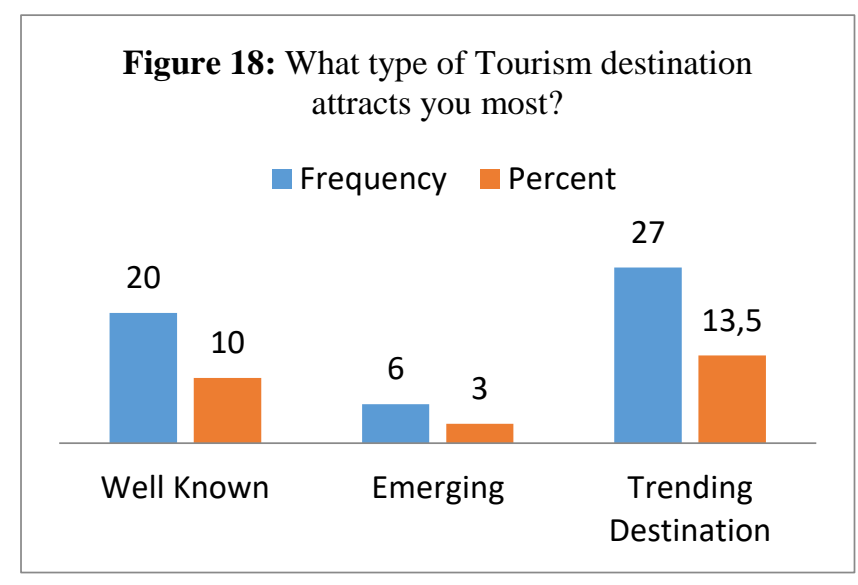

This question was asked to find out reasoning behind a travelers decision to choose an international destination over others. This study found that trending destinations are far more preferred $(13.5 \%)$ than any other destination and 10 percent respondents travelled well known destination in their international trip. 
Figure 19: What is your favorite style of Itinerary in a foreign land?

Frequency Percent

22

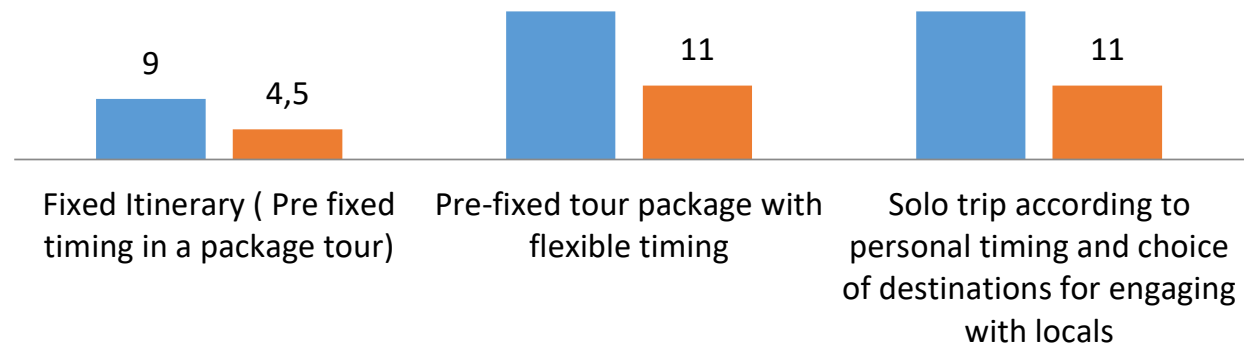

This Figure 19 shows that, about 11 percent respondents preferred both pre-fixed tour package with flexible timing and solo trip according to personal timing and choice of destinations for engaging with locals.

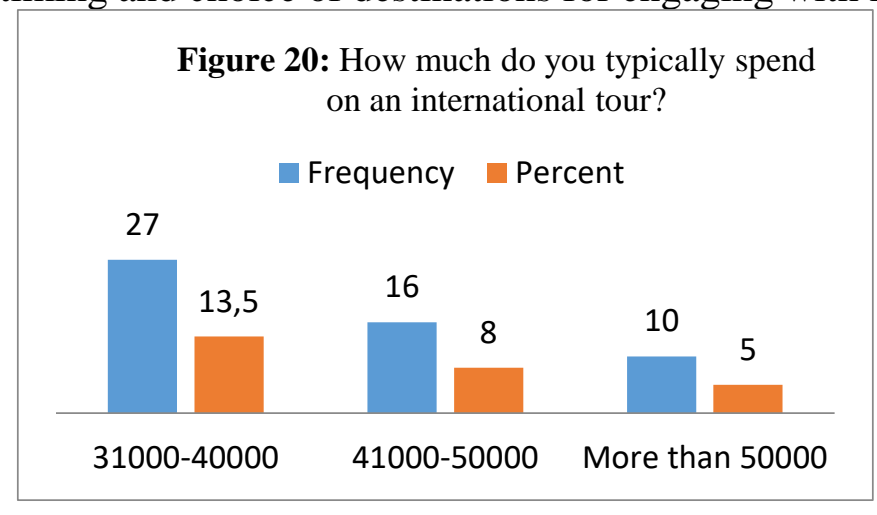

Figure 20 reveals the spending behavior of young respondents in an international tour. Typically an international tour is costlier than a domestic tour. In this study 13.5 percent respondents spend taka 31000 to 40000 on their vacation and 8 percent respondents spend taka 41000 to 50000 .

Figure 21: From where do you get most information?

\section{- Frequency $\quad$ Percent}

43

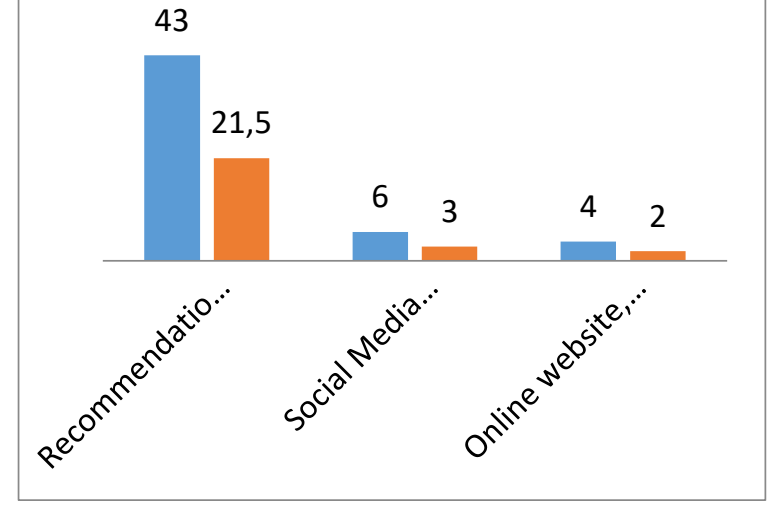

Figure 21 shows that about 21.5 percent people influenced by word of mouth communication from their friends and family member while they choose their travel activities. Word of mouth communication is the most influential medium of communication which is recognized by all the academicians. After that, social media (3 percent) and online review ( 2 percent) are the major influential factor for the young travelers while they choose international travel destination. 
Figure 22: What is your preferred length of international tourism and leisure activity?

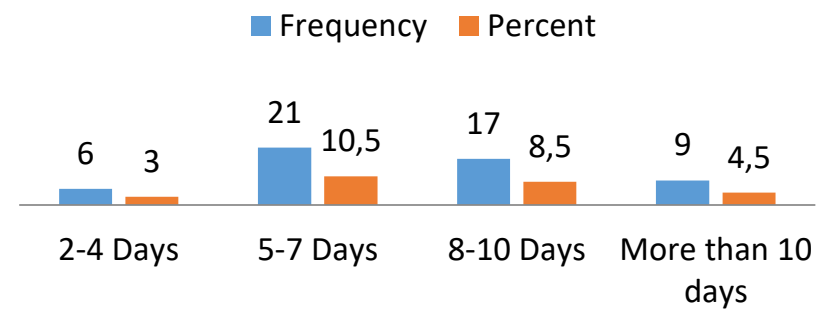

Generally, tourists tend to spend more time in an international tour than a domestic tour. This study also reveals that almost 10.5 percent respondents spend 5 to 7 days in international tour and 8.5 percent spend 8 to 10 days at their vacation destination

\section{Research Implications and Conclusion}

This study shows a glimpse of travel and tourism market in Bangladesh dedicated for youth tourism. This study attempted to find out the perception of the Bangladeshi young people regarding leisure, their leisure pursuits and to discover influences of different demographic and socio-economical variables over their leisure activities. Which means it was an effort to reveal the existing motivators for leisure, travel behavior, decision making process and leisure activities of the Bangladeshi young tourists.

The study also tried to explicitly explore about the areas like, time allotted for leisure activities, their preferred season to travel, their common attitudes towards leisure time and supporting issues that motivate them to travel. The means of leisure spending have been changing over the period of time. The domestic tourist destination visit becomes popular with the rising trend of disposable income and available leisure time during last couple of years. It has been observed in this study that there has been a metamorphosis in leisure concept and behavior which would continue in future. Tourism policymakers need to understand this drift in the market.

The findings offered valuable information to attend business opportunities by providing 'the existing pattern of peoples' leisure behavior and its changing trends. At the same time, the policy makers should develop strategies by considering these changes in market.

The study suggests that the way of leisure spending have been altering over the period of time. The vibrant young travelers of Bangladesh are bringing their constructive influence in this business for the last decade with their ever changing test and demand being constantly updated with worldwide trend. 


\section{References:}

1. Ahmed, S. A., Barber, M., \& Astous, A. (1998). Segmentation of the Nordic winter sun seekers, market. Journal of Travel and Tourism Marketing, 7(1), 39\}63.

2. Carr, N. (2002) The tourism-leisure behavioural continuum. Annals of Tourism Research, 29, 972-986

3. Chadee, D. D., \& Cutler, J. (1996). Insights into international travel by students. Journal of Travel Research, 35(2), 75-80.

4. Chen, H., Chen, P. J., \& Okumus, F. (2013). The relationship between travel constraints and destination image: A case study of Brunei. Tourism Management, 35, 198-208.

5. Crompton, J. L. \& McKay, S.L. (1997). Motives of visitors attending festival events. Annals of Tourism Research, 24 (2), 425-439.

6. d'Anjou, A. (2004). Youth tourism in Canada: A situational Analysis of an Overlooked Market. Ottawa: Youth Tourism Consortium of Canada.

7. Goodrich, J. N. (1978). The relationship between preferences for and perceptions of vacation destinations:Application of a choice model. Journal of Travel Research, 17(2), 8 13.

8. Holloway, J. C. (1986). The business of tourism. London:Longman Publishing Ltd.

9. Holloway, J. C. (2004), Marketing for Tourism, Prentice Hall, New York.

10. Holmes, K., Lockstone-Binney, L., \& Deery, M. (2013). Constraints across the volunteer life cycle: Implications for Australian tourism organisations. Paper presented at the The Council for Australasian University Tourism and Hospitality Education (CAUTHE), 11-14 February, Christchurch, New Zealand.

11. Ian, L. T., \& Musa, G. (2008). Uncovering the international backpackers to Malaysia. In K. Hannam \& I. Ateljevic (Eds.), Backpacker tourism: Concepts and profiles. Clevedon; New York; Ontario: Channel View Publications.

12. Iso-Ahola, S. (1989). Motivation for leisure. In E. L. Jackson \& T. L. Burton (Eds.), Understanding leisure and recreation: Mapping the past, charting the future (pp. 247-280). State College, PA: Venture.

13. Kim, K.-Y., \& Jogaratnam, G. (2002). Travel motivations: A comparative study of Asian international and domestic American college students. Journal of Travel \& Tourism Marketing, 13(4), 6182.

14. Lawa, E. (1995), Tourist Destination Management: Issues, Analysis and Policies, London, Routledge. 
15. Leontido L. (1994). Gender dimensions of tourism in Greece: Employment, substructuring and restructuring. In V. Kinnaird \& D. Hall (Eds.), Tourism: A gender analysis (pp. 74-104). Chichester: Wiley.

16. March, R. G., \& Woodside, A. G. (2005), Tourism Behavior: Travelers' Decisions and Actions, CABI Publishing, Cambridge.

17. Murphy, L., \& Pearce, P. L. (1995). Young budget travelers: Backpackers in Australia. Annals of Tourism Research, 22(4), 819843.

18. Neulinger, J. (1974). The psychology of leisure: Research approaches to the study of leisure. Springfield, IL: Charles C. Thomas.

19. Papatheodorou, A. (2006), Managing Tourism Destinations, Northampton, Edward Elgar Publishers.

20. Prayag, G., Rezwan, J., \& Hosany, S. (2013). When Middle East meets West: An exploratory study of UAE young potential visitors' motivations and perceptions of Paris as a luxury destination. Paper presented at the The Council for Australasian University Tourism and Hospitality Education (CAUTHE), 11-14 February, Christchurch, New Zealand. .

21. Reisinger, Y., \& Mavondo, F. (2004). Modelling psychographic profiles: A study of the U.S. and Australian student travel market. Journal of Hospitality \& Tourism Research, 28(1), 44-65.

22. Richards, G., \& Wilson, J. (2003). Today's youth travellers: Tomorrow's global nomads. New horizons in independent youth and student travel. Amsterdam: International Student Travel Confederation (ISTC) and the Association of Tourism and Leisure Education (ATLAS).

23. Shih, D. (1986). "VALs as a tool of tourism market research: The Pennsylvania experience", Journal of Travel Research, 24(4), pp. 2-11.

24. Sung, S., \& Hsu, C. H. C. (1996). International students' travel characteristics: An exploratory study. Journal of Travel \& Tourism Marketing, 5(3), 277-283.

25. Szántó Miklós (1967). Életmód, mûvelôdés, szabadidô. Budapest, Akadémiai Kiadó, 13. o. Az idézett mû a továbbiakban: Szántó Miklós [1967]

26. UNWTO. (2012). The Middle East outbound travel market with special insight into the image of europe as a destination. Madrid: UNWTO.

27. Wall, G. \& Mathieson, A. (2006). Tourism: Change, Impacts and Opportunities. Harlow: Pearson Education Limited. 
28. Yau, O. H. M., \& Chan, C. F. (1990). Hong Kong as a travel destination in South-East Asia:A multidimensional approach. Tourism Management, 11(2), 123\}132. 